\title{
Internal and external export barriers: analysis from Serbian SME's point of view
}

\author{
Article history: \\ Received: 21 January 2014 \\ Sent for revision: 10 February 2014 \\ Received in revised form: 20 March 2014 \\ Accepted: 3 May 2014 \\ Available online: 1 July 2014
}

\begin{abstract}
Influence of enterprise characteristics, i.e. size, length of export experience, capital ownership and type of industry, on export barriers perception in case of Serbian manufacturing SMEs exporters was researched in this paper. Aims of the study were to identify factors that may pose export barriers for Serbian SMEs, rank perceived barriers, spotting differences by different groups of SMEs, and examine correlations between SMEs characteristics and export barriers perception. Main hypothesis was that SMEs from Serbia perceive factors that may pose export barriers similar to exporters in other countries, but degree and magnitude of influence depend on enterprise's characteristics. The empirical research has been conducted through a survey and 137 exporters taking part in it, which gave response rate of $35.49 \%$. For collected data processing and analyzing descriptive statistics, differences among groups and correlation tests were employed. Results showed that influences of the enterprise size and foreign capital ownership on export barriers perception are positive, which means that small and domestic enterprises face larger barriers to export compared to medium and foreign ones.
\end{abstract}

Key words: Export barriers, SME, perception, enterprise characteristics, factors of internal and external environment, Serbia

\footnotetext{
${ }^{1}$ University of Novi Sad, Faculy of Economics in Subotica

${ }^{2}$ University of Belgrade, Faculty of Economics, PhD Student, predrag.radojevic@open.telekom.rs
} 
Sudarević T., Radojević D.P.: Internal and external export barriers: analysis from...

\section{Unutrašnje i spoljne izvozne prepreke: analiza sa stanovišta MSP iz Srbije}

Apstrakt: $U$ ovom radu se istražuje uticaj karakteristika preduzeća, odnosno veličine, dužine izvoznog iskustva, vlasništva nad kapitalom i vrste industrije, na opažanje izvoznih prepreka u slučaju proizvodnih MSP izvoznika iz Srbije. Njeni ciljevi bili su da utvrdi činioce koji mogu da predstavljaju izvozne prepreke za domaća MSP, rangiranje opaženih prepreka, uočavanje razlika između različitih grupa MSP i ispitivanje korelacije između odlika MSP $i$ opažanja izvoznih prepreka. Osnovna hipoteza rada bila je da MSP iz Srbije opažaju činioce koji mogu da predstavljaju izvozne prepreke slično izvoznicima u drugim zemljama, a da stepen i obim uticaja zavise od odlika preduzeća. Empirijsko istraživanje je sprovedeno putem ankete uz učešće 137 izvoznika što je dalo stopu odziva od 35.49\%. Za obradu prikupljenih podataka korišćena je deskriptivna statistika, testovi za utvrđivanje razlika između grupa i korelacija. Rezultati su pokazali da su uticaji veličine preduzeća i stranog vlasništva nad kapitalom na opažanje izvoznih prepreka pozitivni, što znači da se mala i preduzeća sa domaćim kapitalom suočavaju sa većim izvoznim preprekama $u$ odnosu na srednja $i$ ona sa inostranim kapitalom.

Ključne reči: izvozne prepreke, MSP, opažanje, odlike preduzeća, činioci unutrašnje sredine i spoljnog okruženja, Srbija

\section{Introduction}

Expansion of export is vital for development and health of every national economy Export improves trade and payment balances, helps dealing with unemployment, boosts profitability, increases capacity utilization, and leads to better competitiveness (Koksal, 2008). With 11,353 million dollars Serbia accounts for less than $0.07 \%$ of global export and about $1.2 \%$ of export of all East Europe (UNCTAD Handbook of Statistics, 2013, p. 6, 14). The low levels of domestic exports have caused a lot of concern in academic and professional circles, and debate about export as a very important part of new economic development policy (Savić \& Bosković, 2011; Mićić \& Zeremski, 2011; Čajka \& Mašić, 2013).

Although some essential sources of data in area of external trade in Serbia exist (for example: Republički zavod za statistiku, 2013), the debates about exports in transition economies, to which Serbia belongs, have generally suffered from lack of more empirical enterprise level data, especially for small and medium enterprises [hereafter, SMEs] (Neupert, Baughn, \& Dao, 2006; 
Sudarević T., Radojević D.P.: Internal and external export barriers: analysis from...

Che Senik, Scott-Ladd, Entrekin, \& Khairul, 2011). For that reason researches in the field of SMEs export have multiple needs. First, the researches of export are primarily focused on large enterprises and multinationals (Rundh, 2007). Second, even if SMEs export is taken in consideration, it generally covers SMEs from developed economies (Singh, 2009). Third, as more SMEs engage in export today, there is a growing interest in this process uniqueness (Lages, Silva and Styles, 2009). Fourth, although globalization has removed many barriers and enabled wider access for SMEs to export, SMEs still face them in terms of resources constraints (Dhanaraj \& Beamish, 2003). All those undermines the generalization, especially on SMEs from one small, transition economy like Serbian, in which SMEs contributed with $98.8 \%$ of all business and $69 \%$ of employment, but only $19 \%$ of manufacturing, $33 \%$ of GDP, $46,5 \%$ of export and $61,7 \%$ of foreign trade deficit (OECD, 2012, p. 230; Ministarstvo finansija i privrede, 2012, p. 8) Taking into account that enterprise's decision about export is influenced by export barriers perception, main motivation of this paper stems from desire to conduct research of Serbian SME's point of view and contribute to understanding of export barriers in one specific context.

A substantial body of empirical work has identified many factors that influence export, but, the lack of agreement among researchers on the degree and magnitude of the influence of certain enterprise's characteristics on export barriers perception makes this issue actual.

Aims of this paper are to identify factors that may pose export barriers for Serbian SMEs, rank perceived barriers, spot differences by different groups of SMEs, and examine correlations between certain SME's characteristics and export barriers perception. Purpose of the listed is to obtain information on the direction to which the export policy in Serbia should be oriented and in which way SME's management has to reorganize the exporting in order to mitigate or eliminate some export barriers.

For achieving the set purpose and aims, this paper is structured as follows. First, a literature review about the various factors that may pose barriers to export and certain SME's characteristics relations was made. Second, export barriers were classified. Those gave possibility for conceptual framework for empiric research building and hypotheses set up. That is followed by the methodology and research results sections. The paper ends with a discussion and conclusion with research findings implications on economy policy makers, SME's management and future researches.

\section{Literature review}

Export activity from SME's point of view has been the focus of a significant body of theoretical and empirical research, employing resource-based view of 
Sudarević T., Radojević D.P.: Internal and external export barriers: analysis from...

enterprise and stage theory of internationalization as principally theoretical frameworks (McAuley, 2010; Dhanraj and Beamish, 2003). Theory quotes that large and multinational enterprises more likely perceive export barriers as smaller because they possess greater resource capacity, enabling them to better serve export markets. SMEs are resource constrained and they have been largely hindered by export barriers (Brouthers et al., 2009; Hall and Cook, 2009).

Researchers in the field of international business and marketing have identified several factors that can influence export from the enterprise level. According to some authors there are factors related to enterprise knowledge, internal resources, procedures and export markets (Kneller \& Pisu, 2011). Knowledge- related factors limit information from export markets collecting, while internal resources refer to financial, organizational and marketing constraints. Procedural_factors apply to procedures, non-custom limitations and tariffs. Export markets related factors include cooperation with export partners, business circumstances in export markets, offer and demand trends, fluctuations of currency exchange rates, activities of competition, governments regulative and culture aspects.

Other authors claim that there are external, operational, internal and informational factors that may pose export barriers (Tesfom and Lutz, 2006; Neupert et al., 2006). External factors comprise price of capital for export financing, fluctuations in currency exchange rates, foreign completion, and national policies toward exporters. Operational factors include procedural, transactional, logistic, and transport aspects. Internal factors refer to organizational resources and capacities of enterprise. Informational factors apply to availability of information for export conducting process.

Third group of authors underline that export is influenced by internal forces, stemming from enterprise's characteristics, and external forces formed by domestic business environment and export markets characteristics (Sousa, Martinez-Lopez \& Coelho, 2008).

Mentioned export barriers have been heterogeneously perceived by different types of enterprises depending on their characteristic. For researchers the export barriers perception have usually been explored taking into consideration enterprise size, length of export experience capital ownership, and type of industry that enterprise belongs to.

Evidence from empirical studies suggests that enterprise size matters for export, but degree and magnitude of that influence vary. Some authors found positive influence of size on export barriers perception, because size affects scale of production, management and marketing capabilities, problem solving, R\&D investments, attitudes, needs and practices on export markets (Majocchi, Bacchiocchi, \& Mayrhofer, 2005; Larimo, 2007). Large and multinational 
Sudarević T., Radojević D.P.: Internal and external export barriers: analysis from...

enterprises given their superior resources can deal with export barriers more effectively than SMEs and perceive them as less influenced. But not all studies have confirmed this result. Some found smaller enterprises dealing with export barriers more successfully than larger ones, or found no influence of size on export barriers (Pla-Barber \& Alegre 2007; Saixing et al., 2009).

The accumulation of export experience leads to better knowledge, understanding and possibility for overcoming export barriers and therefore that kind of enterprises perceive export barriers as smaller (Majocchi et al., 2005; Alvarez, 2007). On the other hand, some opposite and neutral results can be found also (Andersson, Gabrielsson \& Wictor, 2004; Larimo, 2006).

Studies dealing with capital ownership impact on export barriers perception are mostly conducted in the transition and developing economies with mixed results too. Ones claim that foreign ownership positively impact export barriers perception and overcoming (Cole, Elliott \& Virakul, 2010; Filatotchev, Stephan \& Jindra, 2008). On the other hand, the others found no or negative impact of capital ownership on export barriers (Wignaraja, 2008; Jenkins, 1979).

Type of industry is very frequently researched characteristic of enterprise related to export barriers, and it has been usually seen in the light of technology level of some industries. However, these studies have opposite results too. Ones emphasize positive impact of belonging to high-tech industries on export barriers perception (Rodriguez \& Rodriguez, 2005; Richardson, 2011). The others state that there is no, or there is negative impact of belonging to high-tech industries on export barriers perception (Gao, Murray, Kotabe \& Lu, 2010; Chetty \& Hamilton, 1993).

\section{Conceptual Framework and Hypotheses}

A list of factors that may pose barriers to export from previous studies has been mainly followed up in this paper, with addition of two new factors. This refers to national export branding policy, since there is no internationally recognized Serbian export brand, and exporters associations issues, since process of clustering has just started.

All factors that may pose export barriers have been divided into two groups factors of internal and external environment, as presented in Fig. 1. This classification was chosen because it allows clear dividing of recommendations for SME's management and economic policy makers in the closing section of paper. 
Sudarević T., Radojević D.P.: Internal and external export barriers: analysis from...

Figure 1. Research conceptual framework

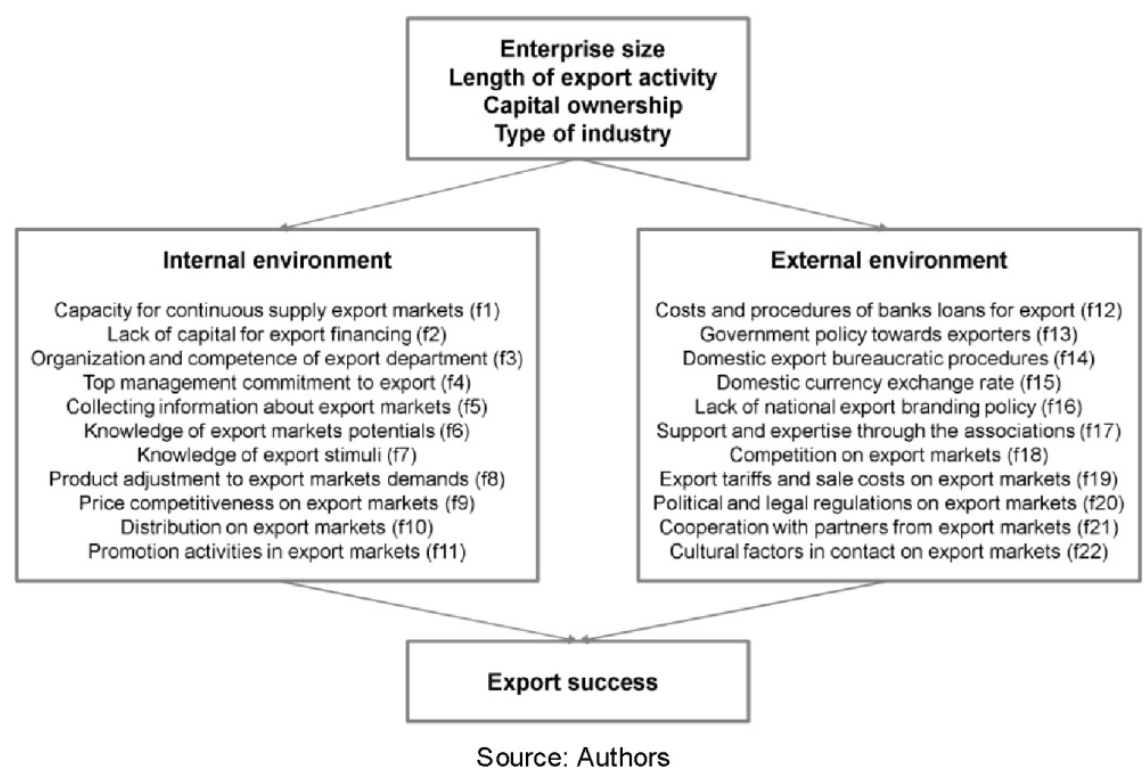

Assuming that main hypothesis is that SMEs from Serbia perceive factors that may pose export barriers similar to exporters in other countries, particular hypotheses and their alternatives for empirical research were made on influence of certain SME's characteristics based on previous literature review findings:

H1: Size positively affects export barriers perception.

H2: Length of export business positively affects export barriers perception.

H3: Foreign capital ownership positively affects export barriers perception.

H4: Belonging to high-tech industries positively affects export barriers perception.

\section{Methodology}

The empirical research on influence of SMEs' characteristics on export barriers perception was conducted through a survey. Questionnaire had two parts. The first one was composed of data on size, length of export business, ownership of capital and type of industry enterprises belong to. Independent variables were formed on the basis of these data. The second part included 22 factors from enterprises' internal and external environment that may pose export barriers. Dependent variables were formed on the basis of these data. 
Sudarević T., Radojević D.P.: Internal and external export barriers: analysis from...

Respondents provided assessments on the scale ranging from 1 to 5 depending on the level of their influence, but only factors with average rates higher than 2.5 have been considered as barriers to export.

The basic sample for research consisted of all of the 386 Serbian manufacturing small and medium enterprises with export income of at least one million dollars in 2012 according to the Serbia Investment and Export Promotion Agency data. Questionnaires were sent to respondents by e-mail.

Respondents first received an e-mail with the questionnaire attached, followed by four further follows-ups. In total 148 enterprises took a part in the research, but 137 questionnaires were completely filled-in. Hence respond rate in this research was $35.49 \%$. This is considered satisfactory since average respond rate in surveys involving business respondents is approximately $30 \%$ (Dillman, 2007, p. 323). Main data on enterprises that took part in the survey are presented in the Table 1.

Table 1. Caracteristics of enterprises took part in the survey

\begin{tabular}{|c|c|c|c|}
\hline \multicolumn{4}{|c|}{ Size of enterprise } \\
\hline \multicolumn{2}{|c|}{ Small enterprises } & \multicolumn{2}{|c|}{ Medium enterprises } \\
\hline \multicolumn{2}{|c|}{ Frequency $(\%)$} & \multicolumn{2}{|c|}{ Frequency $(\%)$} \\
\hline \multicolumn{2}{|c|}{$40(29.2)$} & \multicolumn{2}{|c|}{$97(70.8)$} \\
\hline \multicolumn{4}{|c|}{ Length of export business } \\
\hline Up to 5 years & 6 to 20 years & 21 to 50 years & Over 50 years \\
\hline Frequency (\%) & Frequency $(\%)$ & Frequency (\%) & Frequency $(\%)$ \\
\hline $10(7.3)$ & $82(59.9)$ & $24(17.5)$ & $21(15.3)$ \\
\hline \multicolumn{4}{|c|}{ Ownership of capital } \\
\hline \multicolumn{2}{|c|}{$\begin{array}{l}\text { Domestic and dominant } \\
\text { domestic }\end{array}$} & \multicolumn{2}{|c|}{$\begin{array}{c}\text { Foreign and dominant } \\
\text { foreign }\end{array}$} \\
\hline \multicolumn{2}{|c|}{ Frequency $(\%)$} & \multicolumn{2}{|c|}{ Frequency $(\%)$} \\
\hline \multicolumn{2}{|c|}{$87(63.5)$} & \multicolumn{2}{|c|}{$50(36.5)$} \\
\hline \multicolumn{4}{|c|}{ Type of industry } \\
\hline $\begin{array}{c}\text { Low } \\
\text { technology }\end{array}$ & $\begin{array}{c}\text { Mid-low } \\
\text { technology }\end{array}$ & $\begin{array}{l}\text { Mid-high } \\
\text { technology }\end{array}$ & $\begin{array}{c}\text { High } \\
\text { technology }\end{array}$ \\
\hline Frequency (\%) & Frequency $(\%)$ & Frequency $(\%)$ & Frequency $(\%)$ \\
\hline $68(49.6)$ & $40(29.2)$ & $17(12.4)$ & $12(8.8)$ \\
\hline
\end{tabular}

Internal consistency and reliability in this survey measured by Cronbach's alpha coefficient was 0.824 , which is indicated as good (DeVellis, 2003, p. 90).

Several tests have been conducted in order to establish whether it is likely that perceptions of enterprises taking part in the survey may differ significantly from those that failed to reply in accordance with relevant practice (Armstrong \& Overton, 1977; Weisberg, 2005, p. 159). However, those tests haven't discovered statistically significant differences. 
Sudarević T., Radojević D.P.: Internal and external export barriers: analysis from...

For data processing and analyzing, the descriptive statistics techniques and tests for statistically significant differences existence were used, checking different groups of enterprises that were sorted by their characteristics. The one way analysis of variance of different groups (ANOVA) and the KruskalWallis test (K-W test), when there were three and more groups, and independent sample t-test and Mann-Whitney $U$ test (M-V $U$ test), when there were two groups within independent variable, were employed. Both types of tests have been used to ensure that the results were not influenced by mathematical bias inherent to parametric and nonparametric statistical analysis tests. Correlation analysis was employed to check relations among independent and dependent variables. Values obtained by analysis of differences between groups and correlation were assessed by Cohen's criteria (Ellis, 2010, pp. 40-42).

\section{Research Findings}

Research findings are presented in three separate parts - first, internal and external environment factors ranking, second differences in evaluating internal and external environment factors depending on enterprises' characteristics and third correlation analysis between enterprises' characteristics and internal and external environment factors.

\subsection{Factors of enterprises internal and external environment ranking}

Means of explored factors that may pose barriers to export are shown on Fig. 2.

Within factors of internal environment the largest barriers are lack of capital for export financing $(M=3.49)$, price competitiveness achieving $(M=3.27)$ and organization of promotion activities $(M=3.22)$. Other barriers include collection of information about export markets $(M=2.88)$, adjustment of products to export markets demands $(M=2.82)$ and distribution $(M=2.59)$. Rests of the factors are not perceived as export barriers.

Amongst factors of external environment the largest barriers are competition on export markets $(M=4.29)$ and cost and procedures of bank loans for export financing $(M=4.18)$. Also, significant barriers are domestic currency exchange rate $(M=3.94)$ and government policy toward exporters $(M=3.53)$. Others include lack of national export branding policy $(M=3.06)$, export tariffs and sale cost on export markets $(M=2.75)$, and political and legal regulations on export markets $(M=2.73)$. 
Sudarević T., Radojević D.P.: Internal and external export barriers: analysis from...

Figure 2. Internal and external environment factors rancing*

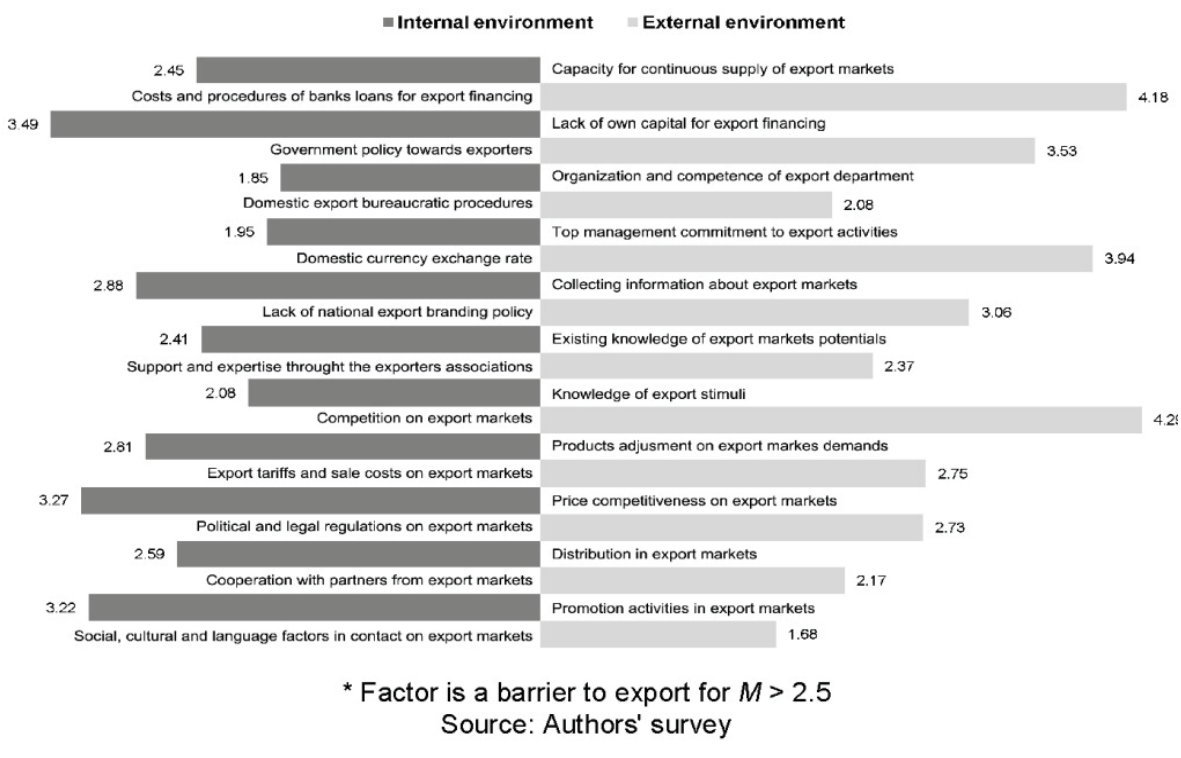

\subsection{Differences in evaluation of internal and external environment factors depending on enterprises' characteristics}

The independent samples t-tests results, followed by M-W U tests, as shown in Table 2, find existence of three statistically significant differences in evaluation of explored factors of internal environment depending on the enterprise's size:

1) Capacity for continuous export markets supply, $t(135)=2.524, p=0.013$, $U=1502.500, z=-2.142, p=0.032$. The scope of this difference totals $\eta^{2}=$ 0.045 , and is considered as small. It means that small enterprises $(M=$ 2.8250, $S D=1.31826$ ) have been influenced by this factor a bit more than medium ones $(M=2.2990, S D=1.01206)$.

2) Lack of capital for export financing, $t(135)=4.198, p=0.000, U=$ $1100.000, z=-4.119, p=0.000$. The scope of this difference totals $\eta^{2}=$ 0.115 , and is considered as large. It means that small enterprises $(M=$ $4.1000, S D=0.98189$ ) have been influenced by this factor much more than medium ones $(M=3.2474, S D=1.11832)$.

3) Promotion activities, $t(135)=3.172, p=0.002, U=1298.500, z=-3.184$, $p=0.001$. The scope of this difference totals $\eta^{2}=0.069$, and is considered as medium. It means that small enterprises $(M=3.6750, S D=0.85896)$ have 
Sudarević T., Radojević D.P.: Internal and external export barriers: analysis from...

been influenced by this factor more than medium ones $(M=3.0412, S D=$ 1.13576)

Table 2. Differences in evaluation of internal environment factors depending on the enterprises size

\begin{tabular}{|c|c|c|c|c|c|}
\hline $\begin{array}{c}\text { Internal } \\
\text { Environment } \\
\text { Factors }\end{array}$ & \multicolumn{2}{|c|}{ t-test } & \multicolumn{3}{c|}{ M-W U test } \\
\cline { 2 - 6 } & $t$ & $p$ & $U$ & $z$ & $p$ \\
\hline f1 & 2.524 & 0.013 & 1502.500 & -2.142 & 0.032 \\
\hline f2 & 4.198 & 0.000 & 1100.000 & -4.119 & 0.000 \\
\hline f3 & -0.459 & 0.647 & 1923.000 & -0.086 & 0.931 \\
\hline f4 & 0.808 & 0.421 & 1786.500 & -0.777 & 0.437 \\
\hline f5 & 1.142 & 0.255 & 1716.000 & -1.100 & 0.271 \\
\hline f6 & 0.913 & 0.363 & 1740.000 & -0.980 & 0.327 \\
\hline f7 & 0.690 & 0.491 & 1743.000 & -0.978 & 0.328 \\
\hline f8 & 0.056 & 0.955 & 1915.500 & -0.122 & 0.903 \\
\hline f9 & 0.388 & 0.699 & 1848.500 & -0.453 & 0.650 \\
\hline f10 & 1.901 & 0.059 & 1563.000 & -1.837 & 0.066 \\
\hline f11 & 3.172 & 0.002 & 1298.500 & -3.184 & 0.001 \\
\hline \multicolumn{7}{|c|}{ Difference is statistically significant at p< 0.05} \\
\end{tabular}

The independent samples t-tests results, followed by M-W U tests, as shown in Table 3 find one statistically significant difference in evaluation of explored factors of external environment depending on the enterprises size:

Table 3. Differences in evaluation of external environment factors depending on the enterprises size

\begin{tabular}{|c|c|c|c|c|c|}
\hline \multirow{2}{*}{$\begin{array}{c}\text { External } \\
\text { Environment } \\
\text { Factors }\end{array}$} & \multicolumn{2}{|c|}{ t-test } & \multicolumn{3}{|c|}{$\mathrm{M}-\mathrm{W} \cup$ test } \\
\hline & $t$ & $p$ & $U$ & $z$ & p \\
\hline $\mathrm{f} 12$ & 2.028 & 0.045 & 1509.000 & -2.197 & 0.028 \\
\hline f13 & 1.916 & 0.057 & 1536.500 & -1.985 & 0.057 \\
\hline f14 & -0.408 & 0.684 & 1777.000 & -0.811 & 0.417 \\
\hline f15 & 1.711 & 0.089 & 1545.500 & -1.999 & 0.076 \\
\hline f16 & 1.301 & 0.195 & 1702.000 & -1.161 & 0.246 \\
\hline f17 & 1.009 & 0.315 & 1752.000 & -0.928 & 0.353 \\
\hline f18 & 1.685 & 0.094 & 1655.000 & -1.475 & 0.140 \\
\hline f19 & -0.012 & 0.990 & 1937.000 & -0.015 & 0.988 \\
\hline $\mathrm{f} 20$ & -0.748 & 0.456 & 1819.000 & -0.598 & 0.550 \\
\hline $\mathrm{f} 21$ & 0.583 & 0.561 & 1809.500 & -0.647 & 0.518 \\
\hline $\mathrm{f} 22$ & 0.711 & 0.478 & 1935.500 & 0.981 & -0.124 \\
\hline
\end{tabular}


Sudarević T., Radojević D.P.: Internal and external export barriers: analysis from...

1) Costs and procedures of bank loans to finance exports, $t(135)=2.028, p=$ $0.045, U=1509.000, z=-2.197, p=0.028$. The scope of this difference totals $\eta^{2}=0.029$, and is considered as small. It means that small enterprises ( $M$ $=4.4000, S D=0.77790$ ) have been influenced by this factor a bit more than medium ones $(M=4.0928, S D=0.81755)$.

The ANOVA results, followed with $\mathrm{K}-\mathrm{W}$ tests, as shown in Table 4, find the two statistically significant differences in evaluation of researched factors of internal environment depending on the length of export business of the enterprises:

1) Commitment of the top management to export activities, among enterprises which have been exporting up to 5 years $(M=2.8000, S D=1.31656)$ on one side, and enterprises that have been exporting from 21 to 50 years $(M=$ 1.7368, $S D=0.94966$ ) and enterprises which have been exporting for over 50 years $(M=1.8667, S D=1.05744)$, on the other side $[F(3,134)=2.744, p=$ $0.046]$. It was confirmed by K-W test, $X^{2}(3, N=134)=8.191, p=0.048$. The scope of this difference totals $\eta^{2}=0.058$, and is considered as medium. It means that enterprises which have been exporting up to 5 years have been influenced by this factor more than enterprises that have been exporting from 21 to 50 years and enterprises which have been exporting for over 50 years.

Table 4. Differences in evaluation of internal environment factors depending on length of export business

\begin{tabular}{|c|c|c|c|c|}
\hline \multirow{2}{*}{$\begin{array}{c}\text { Internal } \\
\text { Environment } \\
\text { Factors }\end{array}$} & \multicolumn{2}{|c|}{ ANOVA } & \multicolumn{2}{|c|}{$\mathrm{K}-\mathrm{W}$ test } \\
\hline & $F$ & $p$ & $x^{2}$ & $p$ \\
\hline $\mathrm{f} 1$ & 1.132 & 0.339 & 2.234 & 0.525 \\
\hline f2 & 1.142 & 0.335 & 3.947 & 0.267 \\
\hline f3 & 0.882 & 0.452 & 1.680 & 0.641 \\
\hline $\mathrm{f} 4$ & 2.744 & $0.046^{2}$ & 6.484 & 0.048 \\
\hline f5 & 1.016 & 0.388 & 2.589 & 0.459 \\
\hline f6 & 1.817 & 0.147 & 4.258 & 0.235 \\
\hline f7 & 0.754 & 0.522 & 2.304 & 0.512 \\
\hline f8 & 2.689 & 0.049 & 7.027 & 0.041 \\
\hline f9 & 0.551 & 0.648 & 1.456 & 0.693 \\
\hline f10 & 0.554 & 0.647 & 1.804 & 0.614 \\
\hline f11 & 0.743 & 0.528 & 2.942 & 0.401 \\
\hline
\end{tabular}

Source: Authors' survey

2) Adjustment of products to the demands of export markets between enterprises exporting from 21 to 50 years $(M=2.6053, S D=0.88652)$ on one side, and enterprises exporting for over 50 years $(M=3.1556, S D=0.92823)$ on the other side $[F(3,134)=2.689, p=0.049]$. It was confirmed by the K-W test, $X^{2}(3, N=134)=8,191, p=0.041$. The scope of this difference totals $\eta^{2}=$ 0.056 , and is considered as medium. It means that enterprises which have 
Sudarević T., Radojević D.P.: Internal and external export barriers: analysis from...

been exporting over 50 years have been influenced by this factor more than enterprises that have been exporting from 21 to 50 years.

Regarding external environment, no statistically significant differences were found in evaluating researched factors depending by the length of export experience of enterprises by ANOVA and K-W tests, as shown in Table 5.

Table 5. Differences in evaluation of external environment factors depending on length of export business

\begin{tabular}{|c|c|c|c|c|}
\hline $\begin{array}{c}\text { External } \\
\text { Environment } \\
\text { Factors }\end{array}$ & \multicolumn{2}{|c|}{ ANOVA } & \multicolumn{2}{c|}{ K-W test } \\
\cline { 2 - 5 } & $\boldsymbol{F}$ & $\boldsymbol{p}$ & $\boldsymbol{\chi}^{2}$ & $p$ \\
\hline $\mathrm{f} 12$ & 1.970 & 0.122 & 5.898 & 0.117 \\
\hline $\mathrm{f} 13$ & 0.552 & 0.648 & 1.884 & 0.597 \\
\hline $\mathrm{f} 14$ & 1.943 & 0.126 & 6.276 & 0.099 \\
\hline $\mathrm{f} 15$ & 0.298 & 0.827 & 1.652 & 0.648 \\
\hline $\mathrm{f} 16$ & 1.357 & 0.259 & 4.171 & 0.244 \\
\hline $\mathrm{f} 17$ & 2.252 & 0.085 & 7.335 & 0.062 \\
\hline $\mathrm{f} 18$ & 0.550 & 0.649 & 1.600 & 0.659 \\
\hline $\mathrm{f} 19$ & 0.272 & 0.845 & 1.100 & 0.777 \\
\hline $\mathrm{f} 20$ & 0.518 & 0.671 & 1.935 & 0.586 \\
\hline $\mathrm{f} 21$ & 1.727 & 0.165 & 3.682 & 0.298 \\
\hline $\mathrm{f} 22$ & 1.108 & 0.348 & 1.948 & 0.583 \\
\hline & Source: Authors' survey & \\
\hline
\end{tabular}

Independent samples t-test and the M-W U test, as shown in Table 6 confirms five statistically significant differences in evaluation of the internal environment factors among enterprises with domestic and dominant domestic and firms with the foreign and dominant foreign capital:

1) Capacity to continuously supply export markets, $t(135)=2.667, p=0.019$, $U=1587.000, z=-2.719, p=0.007$. The scope of this difference totals $\eta^{2}=$ 0.050 , and is considered as small. It means that enterprises with domestic and dominant domestic capital $(M=2.6437, S D=1.13072)$ have been influenced by this factor more than enterprises with foreign and dominant foreign capital $(M=2.1200, S D=1.06215)$.

2) Lack of capital to finance export, $t(135)=3.346, p=0.001, U=1466.000$, $z=-3.284, p=0.001$. The scope of this difference totals $\eta^{2}=0.076$, and is considered as medium. It means that enterprises with domestic and dominant domestic capital $(M=3.7356, S D=1.07249)$ have been influenced by this factor more than enterprises with foreign and dominant foreign capital $(M=$ $3.0800, S D=1.15776$ ).

3) Collecting information about export markets, $t(135)=3.936, p=0.000, U=$ 1351.000, $z=-3.822, p=0.000$. The scope of this difference totals $\eta^{2}=$ 0.114 , and is considered as large. It means that enterprises with domestic and 
Sudarević T., Radojević D.P.: Internal and external export barriers: analysis from...

dominant domestic capital $(M=3.1494, S D=1.06234)$ have been influenced by this factor much more than enterprises with foreign and dominant foreign capital $(M=2.4200, S D=1.01197)$.

4) Price competitiveness achievement, $t(135)=3.199, p=0.002, U=$ 1490.000, $z=-3.206, p=0.001$. The scope of this difference totals $\eta^{2}=$ 0.070 , and is considered as medium. It means that enterprises with domestic and dominant domestic capital $(M=3.4828, S D=0.99839)$ have been influenced by this factor more than enterprises with foreign and dominant foreign capital $(M=2.9000, S D=1.07381)$.

5) Promotion activities, $t(135)=8.292, p=0.000, U=682.000, z=-6.999, p$ $=0.000$. The scope of this difference totals $\eta^{2}=0.337$, and is considered as large. It means that enterprises with domestic and dominant domestic capital $(M=3.7241, S D=0.81682)$ have been influenced by this factor much more than enterprises with foreign and dominant foreign capital $(M=2.3600, S D=$ 0.98478).

Table 6. Differences in evaluation of internal environment factors depending on capital ownership

\begin{tabular}{|c|c|c|c|c|c|}
\hline \multirow{2}{*}{$\begin{array}{c}\text { Internal } \\
\text { Environment } \\
\text { Factors }\end{array}$} & \multicolumn{2}{|c|}{ t-test } & \multicolumn{3}{c|}{ M-W U test } \\
\cline { 2 - 6 } & $\boldsymbol{t}$ & $\boldsymbol{p}$ & $\boldsymbol{U}$ & $\boldsymbol{z}$ & $\boldsymbol{p}$ \\
\hline $\mathrm{f1}$ & 2.667 & $0.009^{*}$ & 1587.000 & -2.719 & 0.007 \\
\hline $\mathrm{f} 2$ & 3.346 & $0.001^{*}$ & 1466.000 & -3.284 & $0.001^{*}$ \\
\hline $\mathrm{f3}$ & 0.719 & 0.473 & 2041.000 & -0.644 & 0.520 \\
\hline $\mathrm{f} 4$ & 1.872 & 0.064 & 1871.000 & -1.453 & 0.146 \\
\hline $\mathrm{f5}$ & 3.936 & $0.000^{*}$ & 1351.000 & -3.822 & $0.000^{*}$ \\
\hline $\mathrm{f} 6$ & 1.839 & 0.068 & 1818.500 & -1.650 & 0.099 \\
\hline $\mathrm{f} 7$ & 0.518 & 0.605 & 2086.000 & -0.417 & 0.677 \\
\hline $\mathrm{f} 8$ & 1.400 & 0.164 & 1894.000 & -1.324 & 0.185 \\
\hline $\mathrm{f9}$ & 3.199 & 0.002 & 1490.000 & -3.206 & 0.001 \\
\hline $\mathrm{f} 10$ & 1.470 & 0.144 & 1864.000 & -1.431 & 0.152 \\
\hline $\mathrm{f} 11$ & 8.292 & 0.000 & 682.000 & -6.999 & 0.000 \\
\hline
\end{tabular}

Difference is statistically significant at $p<0.05$ Source: Authors' survey

When external environmental factors are concerned, independent samples ttests followed by $\mathrm{M}-\mathrm{W}$ u tests find statistically significant differences in evaluation of nine factors among enterprises with domestic and dominant domestic and those with foreign or dominant foreign capital, as shown in Table 7: 
Sudarević T., Radojević D.P.: Internal and external export barriers: analysis from...

1) Costs and procedures of bank loans to finance export, $t(135)=5.667, p=$ $0.000, U=1073.500, z=-5.303, p=0.000$. The scope of this difference totals $\eta^{2}=0.192$, and is considered as large. It means that enterprises with domestic and dominant domestic capital $(M=4.4828, S D=0.54692)$ have been influenced by this factor much more than enterprises with foreign and dominant foreign capital $(M=3.6600, S D=0.93917)$.

2) Government's policy towards exporters, $t(135)=4.282, p=0.000, U=$ $1309.000, z=-4.023, p=0.000$. The scope of this difference totals $\eta^{2}=$ 0.119 , and is considered as large. It means that enterprises with domestic and dominant domestic capital $(M=3.8276, S D=1.13308)$ have been influenced by this factor much more than enterprises with foreign and dominant foreign capital $(M=3.0200, S D=1.02000)$.

3) Domestic bureaucratic export procedures, $t(135)=2.497, p=0.014, U=$ $1632.000, z=-2.553, p=0.011$. The scope of this difference totals $\eta^{2}=$ 0.044 , and is considered as small. It means that enterprises with domestic and dominant domestic capital $(M=2.2414, S D=1.02260)$ have been influenced by this factor a bit more than enterprises with foreign and dominant foreign capital $(M=1.8000, S D=0.94761)$.

4) Domestic currency exchange rate, $t(135)=4.560, p=0.000, U=$ 1203.000, $z=-4.652, p=0.000$. The scope of this difference totals $\eta^{2}=$ 0.133 , and is considered as large. It means that enterprises with domestic and dominant domestic capital $(M=4.2069, S D=0.79443)$ have been influenced by this factor much more than enterprises with foreign and dominant foreign capital $(M=3.4800, S D=0.95276)$.

5) Lack of a national exports branding policy, $t(135)=7.056, p=0.000, U=$ 898.500, $z=-5.881, p=0.000$. The scope of this difference totals $\eta^{2}=0.269$, and is considered as large. It means that enterprises with domestic and dominant domestic capital $(M=3.5977, S D=1.09396)$ have been influenced by this factor much more than enterprises with foreign and dominant foreign capital $(M=2.1400, S D=1.27791)$.

6) Support and expertise through associations, $t(135)=4.051, p=0.000, U=$ 1315.000, $z=-4.009, p=0.000$. The scope of this difference totals $\eta^{2}=$ 0.118 , and is considered as large. It means that enterprises with domestic and dominant domestic capital $(M=2.6552, S D=1.06561)$ have been influenced by this factor much more than enterprises with foreign and dominant foreign capital $(M=1.8800, S D=1.09991)$.

7) Competition on export markets, $t(135)=3.248, p=0.001, U=1524.000, z$ $=-3.182, p=0.001$. The scope of this difference totals $\eta^{2}=0.072$, and is considered as medium. It means that enterprises with domestic and dominant domestic capital $(M=4.4598, S D=0.71210)$ have been influenced by this 
Sudarević T., Radojević D.P.: Internal and external export barriers: analysis from...

factor more than enterprises with foreign and dominant foreign capital $(M=$ $4.0200, S D=0.84491$ ).

8) Cooperation with partners from export markets, $t(135)=4.261, p=0.000$, $U=1291.500, z=-4.136, p=0.000$. The scope of this difference totals $\eta^{2}=$ 0.119 , and is considered as large. It means that enterprises with domestic and dominant domestic capital $(M=2.4253, S D=0.92299)$ have been influenced by this factor much more than enterprises with foreign and dominant foreign capital $(M=1.7400, S D=0.87622)$.

9) Cultural factors in contacts on export markets, $t(135)=2.309, p=0.023, U$ $=1748.000, z=-2.130, p=0.033$. The scope of this difference totals $\eta^{2}=$ 0.037 , and is considered as medium. It means that enterprises with domestic and dominant domestic capital $(M=1.8161, S D=0.99451)$ have been influenced by this factor a bit more than enterprises with foreign and dominant foreign capital $(M=1.4600, S D=0.78792)$.

Table 7. Differences in evaluation of external environment factors depending on capital ownership

\begin{tabular}{|c|c|c|c|c|c|}
\hline \multirow{2}{*}{$\begin{array}{c}\text { External } \\
\text { Environment } \\
\text { Factors }\end{array}$} & \multicolumn{2}{|c|}{ t-test } & \multicolumn{3}{|c|}{$M-W \cup$ test } \\
\hline & $t$ & $p$ & $U$ & $z$ & $p$ \\
\hline $\mathrm{f} 12$ & 5.667 & 0.000 & 1073.500 & -5.303 & 0.000 \\
\hline f13 & 4.282 & 0.000 & 1309.000 & -4.023 & 0.000 \\
\hline f14 & 2.497 & 0.014 & 1632.000 & -2.553 & 0.011 \\
\hline f15 & 4.560 & $0.000^{\circ}$ & 1203.000 & -4.652 & 0.000 \\
\hline f16 & 7.056 & $0.000^{*}$ & 898.500 & -5.881 & 0.000 \\
\hline f17 & 4.051 & $0.000^{\circ}$ & 1315.000 & -4.009 & 0.000 \\
\hline f18 & 3.248 & 0.001 & 1524.000 & -3.182 & 0.001 \\
\hline f19 & 1.541 & 0.126 & 1878.000 & -1.374 & 0.169 \\
\hline $\mathrm{f} 20$ & 1.401 & 0.163 & 1883.000 & -1.363 & 0.173 \\
\hline f21 & 4.261 & $0.000^{\circ}$ & 1291.500 & -4.136 & 0.000 \\
\hline f22 & 2.309 & $0.023^{*}$ & 1748.000 & -2.130 & 0.033 \\
\hline
\end{tabular}

The ANOVA results, followed by K-W tests, as shown in Table 8 and Table 9, find no statistically significant differences in evaluation of researched factors of internal and external environment depending on the type of industry. 
Sudarević T., Radojević D.P.: Internal and external export barriers: analysis from...

Table 8. Differences in evaluation of internal environment factors depending on industry type

\begin{tabular}{|c|c|c|c|c|}
\hline \multirow{2}{*}{$\begin{array}{c}\text { Internal } \\
\text { Environment } \\
\text { Factor }\end{array}$} & \multicolumn{2}{|c|}{ ANOVA } & \multicolumn{2}{c|}{ K-W test } \\
\cline { 2 - 5 } & $F$ & $p$ & $\chi^{2}$ & $p$ \\
\hline $\mathrm{f1}$ & 0.867 & 0.460 & 1.995 & 0.573 \\
\hline $\mathrm{f} 2$ & 1.928 & 0.128 & 5.196 & 0.158 \\
\hline $\mathrm{f3}$ & 0.278 & 0.841 & 0.691 & 0.875 \\
\hline $\mathrm{f} 4$ & 0.436 & 0.727 & 1.721 & 0.632 \\
\hline $\mathrm{f5}$ & 0.043 & 0.988 & 0.165 & 0.983 \\
\hline $\mathrm{f} 6$ & 0.648 & 0.586 & 2.331 & 0.507 \\
\hline $\mathrm{f} 7$ & 0.772 & 0.512 & 2.139 & 0.544 \\
\hline $\mathrm{f} 8$ & 1.042 & 0.376 & 3.488 & 0.322 \\
\hline $\mathrm{f9}$ & 0.196 & 0.899 & 0.402 & 0.940 \\
\hline $\mathrm{f} 10$ & 0.385 & 0.764 & 1.113 & 0.774 \\
\hline $\mathrm{f} 11$ & 0.830 & 0.480 & 1.314 & 0.726 \\
\hline \multicolumn{5}{|c|}{ Source: Authors' survey } \\
\end{tabular}

Table 9. Differences in evaluation of external environment factors depending on industry type

\begin{tabular}{|c|c|c|c|c|}
\hline \multirow{2}{*}{$\begin{array}{c}\text { External } \\
\text { Environment } \\
\text { Factors }\end{array}$} & \multicolumn{2}{|c|}{ ANOVA } & \multicolumn{2}{c|}{ K-W test } \\
\cline { 2 - 5 } & $\boldsymbol{F}$ & $\boldsymbol{p}$ & $\boldsymbol{\chi}^{2}$ & $p$ \\
\hline $\mathrm{f} 12$ & 1.943 & 0.126 & 3.732 & 0.292 \\
\hline $\mathrm{f} 13$ & 1.100 & 0.351 & 3.347 & 0.341 \\
\hline $\mathrm{f} 14$ & 0.874 & 0.456 & 1.949 & 0.583 \\
\hline $\mathrm{f} 15$ & 1.017 & 0.387 & 1.782 & 0.619 \\
\hline $\mathrm{f} 16$ & 0.954 & 0.416 & 3.234 & 0.357 \\
\hline $\mathrm{f} 17$ & 0.523 & 0.667 & 1.247 & 0.742 \\
\hline $\mathrm{f} 18$ & 2.195 & 0.092 & 5.833 & 0.120 \\
\hline $\mathrm{f} 19$ & 0.720 & 0.542 & 2.050 & 0.562 \\
\hline $\mathrm{f} 20$ & 0.696 & 0.556 & 1.941 & 0.585 \\
\hline $\mathrm{f} 21$ & 2.502 & 0.062 & 5.951 & 0.060 \\
\hline $\mathrm{f} 22$ & 0.099 & 0.960 & 0.200 & 0.978 \\
\hline \multicolumn{5}{|c|}{ Source: Authors' survey } \\
\hline
\end{tabular}

\subsection{Correlation analysis between enterprises' characteristics and internal and external environment factors}

To examine ties between independent and dependant variables, i.e. enterprise characteristics and researched factors of internal and external environment, correlation analysis was employed. Due category nature of independent variables the correlation analysis was conducted by calculating the Spearman's rank correlation (rho). The results of this analysis are shown in Table 10 and Table 11. 
Sudarević T., Radojević D.P.: Internal and external export barriers: analysis from...

Three correlations have been found between enterprise size and factors of internal environment:

1) Weak, $r h o=-0.184$ for capacity to continually supply export markets

2) Medium, rho $=-0.353$ for lack of capital for export financing

3) Weak, $r h o=-0.273$ for promotion activities on export markets organization.

No correlations have been found between length of export business of enterprises and factors of internal environment.

Five correlations have been found between capital ownership of enterprises and factors of internal environment:

1) Weak, $r h o=-0.233$ for capacity to continually supply export markets

2) Weak, $r h o=-0.282$ for lack of capital for export financing

3) Medium, $r h o=-0.328$ for collecting information about foreign markets

4) Weak, $r h o=-0.275$ for price competitiveness on export markets achieving

5) Strong, rho $=-0.600$ for organization of promotion activities on export markets.

No correlations have been found between type of industry of enterprises and factors of internal environment.

Table 10. Correlation of the enterprises' characteristics and the factors of internal environment

\begin{tabular}{|c|c|c|c|c|}
\hline $\begin{array}{c}\text { Factors of } \\
\text { internal } \\
\text { environment }\end{array}$ & $\begin{array}{c}\text { Enterprise } \\
\text { size }\end{array}$ & $\begin{array}{l}\text { Length of } \\
\text { export } \\
\text { business }\end{array}$ & $\begin{array}{c}\text { Capital } \\
\text { ownership }\end{array}$ & $\begin{array}{l}\text { Type of } \\
\text { industry }\end{array}$ \\
\hline $\mathrm{f} 1$ & -0.184 & 0.012 & -0.233 & -0.106 \\
\hline f2 & -0.353 & -0.081 & -0.282 & -0.049 \\
\hline f3 & 0.007 & -0.005 & -0.055 & -0.012 \\
\hline $\mathrm{f4}$ & -0.067 & -0.144 & -0.125 & -0.094 \\
\hline f5 & -0.094 & -0.029 & -0.328 & 0.010 \\
\hline f6 & -0.084 & -0.082 & -0.141 & 0.031 \\
\hline f7 & -0.084 & -0.078 & -0.036 & 0.014 \\
\hline f8 & -0.010 & 0.159 & -0.114 & -0.112 \\
\hline f9 & -0.039 & 0.086 & -0.275 & -0.054 \\
\hline $\mathrm{f} 10$ & -0.158 & 0.091 & -0.123 & 0.062 \\
\hline f11 & $-0.273^{\prime \prime}$ & -0.065 & -0.600 & -0.003 \\
\hline
\end{tabular}

Three correlations have been found between enterprise size and factors of external environment:

1) Weak, rho $=-0.188$ for costs and procedures of bank loans for export financing 
Sudarević T., Radojević D.P.: Internal and external export barriers: analysis from...

2) Weak, rho $=-0.170$ for government's policy towards exporters

3) Weak, rho $=-0.171$ for domestic currency exchange rate.

No correlations have been found between length of export business of enterprises and factors of external environment.

Nine correlations have been found between capital ownership of enterprises and factors of external environment:

1) Medium, rho $=-0.455$ for costs and procedures of bank loans for export financing

2) Medium, rho $=-0.345$ for government's policy towards exporters

3) Medium, rho $=-0.219$ for domestic export bureaucratic procedures

4) Medium, rho $=-0.399$ for domestic currency exchange rate

5) Strong, $r h o=-0.504$ for lack of national export branding policy

6) Medium, rho $=-0.344$ for support and expertise through associations

7) Medium, rho $=-0.273$ for competition on export markets

8) Medium, rho $=-0.355$ for cooperation with partners from export markets

9) Weak, rho $=-0.183$ for cultural differences in contacts on export markets.

Table 11. Correlation of the enterprises' characteristics and the factors of external environment

\begin{tabular}{|c|c|c|c|c|}
\hline Factors & $\begin{array}{c}\text { Enterprise } \\
\text { size }\end{array}$ & $\begin{array}{c}\text { Export } \\
\text { length }\end{array}$ & $\begin{array}{c}\text { Capital } \\
\text { ownership }\end{array}$ & $\begin{array}{c}\text { Type of } \\
\text { industry }\end{array}$ \\
\hline $\mathrm{f} 12$ & -0.188 & -0.165 & -0.455 & -0.043 \\
\hline $\mathrm{f} 13$ & -0.170 & -0.035 & -0.345 & -0.105 \\
\hline $\mathrm{f} 14$ & 0.070 & -0.025 & -0.219 & 0.041 \\
\hline $\mathrm{f} 15$ & -0.171 & -0.061 & -0.399 & -0.050 \\
\hline $\mathrm{f} 16$ & -0.100 & -0.103 & -0.504 & -0.055 \\
\hline $\mathrm{f} 17$ & -0.080 & -0.026 & -0.344 & -0.004 \\
\hline $\mathrm{f} 18$ & -0.126 & -0.059 & -0.273 & -0.090 \\
\hline $\mathrm{f} 19$ & 0.001 & 0.067 & -0.118 & -0.103 \\
\hline $\mathrm{f} 20$ & 0.051 & 0.105 & -0.117 & -0.046 \\
\hline $\mathrm{f} 21$ & -0.055 & -0.014 & -0.355 & -0.156 \\
\hline $\mathrm{f} 22$ & 0.002 & -0.010 & -0.183 & -0.027 \\
\hline \multicolumn{5}{|c}{ Statistically significant at $p<0.05$} \\
\hline
\end{tabular}

No correlations have been found between type of industry of enterprises and factors of external environment.

\section{Discussion}

The results of the empiric research show that Serbian manufacturing SMEs face export barriers in 11 out of 22 explored factors of the internal and exter- 
Sudarević T., Radojević D.P.: Internal and external export barriers: analysis from...

nal environment. Ranked according to their means, perceived export barriers are presented in Table 12.

Table 12. Ranks of export barriers perception by small and medium enterpris-

es

\begin{tabular}{|c|c|c|}
\hline Expolored factors that pose barriers to export & Environment & Mean \\
\hline Competition on export markets & External & 4.2993 \\
\hline Costs and procedures for obtaining loans for export & External & 4.1825 \\
\hline Policy of exchange rate of the domestic currency & External & 3.9416 \\
\hline Government's policy toward exporters & External & 3.5328 \\
\hline Lack of capital for export financing & Internal & 3.4964 \\
\hline Achieving price competitiveness & Internal & 3.2701 \\
\hline Promotion on export markets & Internal & 3.2263 \\
\hline Absence of export branding national policy & External & 3.0657 \\
\hline Collecting information about export markets & Internal & 2.8832 \\
\hline Adjusting products for export market demands & Internal & 2.8175 \\
\hline Export tariffs and sale cost on export markets & External & 2.7518 \\
\hline
\end{tabular}

Source: Authors' survey

The strong competition on export markets is the biggest barrier to them. This is consistent with the results of some other research conducted in developing and transition economies (Neupet et al., 2006; Che Senik et al., 2011; Singh, 2009). However, marketing barriers take an important place among the listed barriers. Even six of them are identified: price competitiveness achieving, adjusting products on export markets demands, promotion activities organization, collecting information about export markets, and distribution originate from internal environment, while absence of national export branding policy derives from external environment. These findings suggest the low level of marketing activities in domestic SMEs exporters and absence of sense in policy makers' minds that national export branding policy is of essential need.

Perceived export barriers affect more small enterprises and enterprises with domestic and dominant domestic capital ownership, especially for the lack of capital for financing export, costs and procedures of bank loans for export financing, organization of promotional activities on export markets, collecting information about export markets, government's policy toward exporters, and lack of national export branding policy.

Statistical differences between group tests and correlation between enterprise size and six out of total 22 explored factors of internal and external environment lead to $H 1$ partial confirmation. Similar result was confirmed in some previous researches (Majocchi et al., 2005; Larimo, 2006).

Small differences between group tests and absence of correlations between enterprise lengths of export business and explored factors of internal and 
Sudarević T., Radojević D.P.: Internal and external export barriers: analysis from...

external environment lead to $H 2$ rejection. In this finding the results of this research are consistent with the results of a few previous studies (Andersson et al., 2004; Larimo, 2006).

Significant statistical differences between group tests and capital ownership correlation with 14 out of total 22 investigated factors of internal and external environment lead to $H 3$ confirmation. Consequently, the results of this paper confirmed the same as in some previous studies (Cole et al., 2010; Filatotchev, et al., 2008).

Almost negligible differences in the assessment of all investigated factors between enterprises classified by the type of industry, none of which is statistically significant, and the lack of correlation between the type of industry and the investigated factors give grounds for rejection of the H4. Accordingly, the results of the research are in compliance with several previous surveys (Gao et al., 2010; Chetty \& Hamilton, 1993).

\section{Conclusion}

The main objective of this paper was to explore the export barriers perception by Serbian manufacturing SMEs. Results show that influence of the enterprise's size on export barriers perception is partial, which means that small enterprises in general face larger barriers to export compared to medium ones. Also, presence of foreign capital positively influences the export barriers perception, which means that enterprises with domestic and dominant domestic capital perceive researched factors as larger barriers in export compared to foreign and dominant foreign capital ones.

From these findings implications can be drawn for the exporters' management, economic policy makers and future researches. Typical resource barriers that SMEs face when trying to export were identified in this paper. As the main problem in export of Serbian SMEs is the lack of competitiveness, and the exporters' managements have to find the way to increase it. Special attention should be paid to improving the product quality and building competitive marketing strategies. Associating in clusters may also help because international practice shows that it could be a successful way to overcome some export barriers. However, these efforts may be unsuccessful if economic policy makers do not take necessary measures. As commercial banks loans for SMEs export financing are expensive, government has to find the way to support them better. Regarding the financing, given the example of some other countries, the export bank with credit lines designed especially for SMEs should be established, and more supporting export guarantee fund has to be made. Providing of special consultancy management and marketing services 
Sudarević T., Radojević D.P.: Internal and external export barriers: analysis from...

to the exporters by government bodies and exporters associations would be welcomed too.

The findings in this paper should be interpreted in the light of several remarks and limitations. First, findings were based on subjective evaluation. This in particular refers to internal environment factors and ability of SMEs to give an objective evaluation of them. Second, as it is typical with most surveys, data were collected from a single respondent in each SME. Thus, results may be influenced by single-respondent bias. Third, conclusions were made on the basis of the successful Serbian SME's opinions. Hence, statistically significant differences and correlation might have been much more relevant if the survey had been taken on a random sample with all exporters from sector of SMEs. Fourth, survey was conducted in one national economy. For other transition countries, the factors may be similar or different and it will be interesting to find out if perceived barriers are the same in other developing countries or not.

In addition, future researches may be involving data collection on a longitudinal basis in order to validate these findings and find causality. Also, it may be supported by qualitative approach for the detection of new factors that may affect exports, which were not explored in this study, and for a deeper understanding of the problems in export and possible ways of surpassing them based on successful exporters' practices.

\section{References}

Alvarez, R. (2007). Explaining export success: firm characteristics and spillover effects. World Development, 35(3), 377-393.

Andersson, S., Gabrielsson, J., \& Wictor, I. (2004). International activities in small firms: examining factors influencing the internationalization and export growth of small firms. Canadian Journal of Administrative Sciences, 21(1), 22-34.

Armstrong, J., \& Overton, T.S. (1977). Estimating non-response bias in mail surveys. Journal of Marketing Research,14(3), 396-402. doi:10.2307/3150783

Brouthers, L.E., Nakos, G., Hadjimarcou, J., \& Brouthers, K.D. (2009). Key factors for successful export performance for small firms. Journal of International Marketing, 17(3), 21-38.

Senik, C.Z., Scott-Ladd, B., Entrekin, L., \& Khairul, K.A. (2011). Networking and internationalization of SMEs in emerging economies. Journal of International Entrepreneurship, 9(4), 259-281.

Chetty, S.K., \& Hamilton, R.T. (1993). Firm-level determinants of export performance: a meta-analysis. International Marketing Review, 10(3), 26-34.

Cole, M., Elliott, R., \& Virakul, S. (2010). Firm heterogeneity, origin of ownership and export participation. World Economy,33(2), 264-291.

Čajka, Z., \& Mašić, B. (2013). Perceptions of sustainable marketing management by export companies in Serbia.Industrija, 41(2), 137-149. 
Sudarević T., Radojević D.P.: Internal and external export barriers: analysis from...

Devellis, R.F. (2003). Scale development: Theory and applications, 2nd ed. Thousand Oaks, California: Sage Publications.

Dhanaraj, C., \& Beamish, P.W. (2003). A Resource-Based Approach to the Study of Export Performance. Journal of Small Business Management, 41(3), 242-261. doi:10.1111/1540-627X.00080

Dillman, D.A. (2007). Mail and Internet surveys - the tailored design method, 2nd ed. Hoboken, New Jersey: John Wiley \& Sons..

Ellis, P.D. (2010). The essential guide to effect sizes: An introduction to statistical power, meta-analysis and the interpretation of research results. Cambridge, UK: Cambridge University Press.

Filatotchev, I., Stephan, J., \& Jindra, B. (2008). Ownership structure, strategic controls and export intensity of foreign-invested firms in transition economies. Journal of International Business $\quad$ Studies, 39(7), $1133-1148$. doi:10.1057/palgrave.jibs.8400404

Gao, G.Y., Murray, J.Y.M., Kotabe, M., \& Lu, J. (2010). A strategy tripod perspective on export behaviour: evidence from domestic and foreign firms based in an emerging economy. Journal of International Business Studies, 41(3), 377-396.

Jenkins, R. (1979). The export performance of multinational corporations in Mexican industry. Journal of Development Studies, 15(3), 89-105.

Kneller, R., \& Pisu, M. (2011). Barriers to exporting: what are they and who do they matter. The World Economy, 34(6), 893-930.

Koksal, M.H. (2008). How export marketing research affects company export performance: evidence from Turkish companies. Marketing Intelligence \& Planning, 26(4), 416-430.

Larimo, J. (2006). Different types of exporting SMEs: similarities and differences in export performance. Advances in International Marketing, 17, 17-62.

Majocchi, A., Bacchiocchi, E., \& Mayrhofer, U. (2005). Firm size, business experience and export intensity in SMEs: a longitudinal approach to complex relationships. International Business Review, 14(6), 719-738.

McAuley, A. (2010). Looking back, going forward: reflecting on research into the SME internationalisation process. Journal of Research in Marketing and Entrepreneurship, 12(1), 21-41. doi:10.1108/14715201011060858

Mićić, V., \& Zeremski, A. (2011). Deindustrijalizacija i reindustrijalizacija privrede Srbije. Industrija, 39(2), 51-68.

-Ministarstvo finansija i privrede. (2012). Izveštaj o malim i srednjim preduzećima $i$ preduzetništvu za 2011. godinu. Beograd, Srbija.

Neupert, K.E., Baughn, C.C., \& Dao, T.T.L. (2006). SME exporting challenges in transitional and developed economies.Journal of Small Business and Enterprise Development, 13(4), 535-545. doi:10.1108/14626000610705732

-OECD. (2012). SME policy index: Western Balkans and Turkey: progress in the implementation of the small business act for Europe. Paris, France: OECD Publishing.

Pla-Barber, J., \& Alegre, J. (2007). Analyzing the link between export intensity, innovation and firm size in a science-based industry. International Business Review, 16(3), 275-293.

Richardson, C.J.R. (2011). Perception of export barriers in a high-tech sector in a less developed country: the case of ICT SMEs in Malaysia. The South East Asian Journal of Management, 5(2), 91-106. 
Sudarević T., Radojević D.P.: Internal and external export barriers: analysis from...

Rodriguez, J.L., \& Rodriguez, R.M.G. (2005). Technology and export behavior: a resource-based view approach.International Business Review, 14(5), 539-557.

Rundh, B. (2007). International marketing behaviour amongst exporting firms. European Journal of Marketing, 41(1/2), 181-198. doi: $10.1108 / 03090560710718175$

Zeng, S., Xie, X.M., Tam, C.M., \& Wan, T.W. (2009). Relationships between business factors and performance in internationalization: An empirical study in China. Management Decision, 47(2), 308-329. doi:10.1108/00251740910938939

Savić, (., \& Bošković, G. (2011). Uticaj svetske ekonomske krize na razvoj srpske industrije. Industrija, 39(4), 86-107.

Singh, D.A. (2009). Export performance of emerging market firms. International Business Review, 18(4), 321-330.

Sousa, C.M.P., Martinez-Lopez, F.J., \& Coelho, F. (2008). The determinants of export performance: a review of the research in the literature between 1998 and 2005. International Journal of Management Reviews, 10(4), 343-374.

Tesfom, G., \& Lutz, C. (2006). A classification of export marketing problems of small and medium sized manufacturing firms in developing countries. International Journal of Emerging Markets, 1(3), 262-281. doi:10.1108/17468800610674480

UNCTAD Handbook of Statistics. (2013). New York: United Nations. Retrieved from http://www.unctad.org

Weisberg, H.F. (2005). The total survey error approach - a guide to the new science of survey research. Chicago, Illinois: The University of Chicago Press.

Wignaraja, G. (2008). Foreign ownership, technological capabilities and clothing exports in Sri Lanka. Journal of Asian Economics, 19(1), 29-39. 